\title{
TUBERCULOSIS AMONG HIV-1-INFECTED SUBJECTS IN A TERTIARY OUT-PATIENT SERVICE IN SÃO PAULO CITY, BRAZIL
}

Jorge CASSEB(1,3), Luiz Augusto M. FONSECA(2), Lucas A. MEDEIROS(1), Claudio R. GONSALEZ(1), Eduardo R. LAGONEGRO(1), Ana Paula Rocha VEIGA(1), Daniela C. DA SILVA(1) Marcelo MENDONÇA(1) \& Alberto J. S. DUARTE(1)

\begin{abstract}
SUMMARY
TB is currently considered to be the most important infectious disease among HIV-1-infected subjects in developing countries, such as Brazil. A retrospective analysis of TB cases was performed, occurring from January 1995 to December 2010 in our cohort of 599 HIV positive patients. The primary outcome was the occurrence of active TB. Forty-one TB cases were diagnosed over this period of 16 years, among 599 HIV positive patients in an open cohort setting in the city of Sao Paulo, Brazil. All-time lowest mean CD4 T cell count at the time of TB diagnosis was 146 and 186 cells $/ \mathrm{mm}^{3}$, respectively. The mean HIV viral $\operatorname{load}_{\text {was }} 5.19 \log _{10}$ copies/mL, and 59\% of the patients were on HAART. TB incidence was 1.47 per 100 person-years, for a total follow-up time of 2775 person-years. The probability of surviving up to 10 years after diagnosis was $75 \%$ for TB patients as opposed to $96 \%$ for patients with other, non-TB opportunistic diseases $(p=0.03)$. TB can be considered a public health problem among people living with HIV in Brazil despite of the widespread use of antiretrovirals for the treatment of HIV infection/AIDS.
\end{abstract}

KEYWORDS: AIDS; Brazil; Co-infection; Incidence; HIV; Mortality; TB.

\section{INTRODUCTION}

In 2008, there were 1.37 million new clinical cases of tuberculosis (TB) and an estimated half-million deaths from TB occurred in HIVinfected persons worldwide ${ }^{3}$. TB is currently considered to be the most important opportunistic infection among HIV-1-infected subjects in Brazil $^{1}$ and is responsible for a substantial proportion of morbidity and mortality among HIV-infected patients, with approximately 70,000 new cases reported annually $y^{3,4,5,13}$. São Paulo State reported 1/3 of Brazilian cases of TB/HIV infection in $2011^{1}$. In fact, $14 \%$ of TB cases in the country are associated with HIV infection and TB is the major cause of death among HIV-infected patients ${ }^{3}$. Although TB/HIV co-infection is a major public health problem in Brazil, few studies have reported its occurrence and clinical outcomes during the HAART era ${ }^{6}$. Thus, the goal of this brief report is to describe the prevalence, incidence and survival of TB among HIV/AIDS patients from an HIV outpatient service located in the City of São Paulo, one of the areas most affected by HIV in Brazil.

\section{MATERIAL AND METHODS}

We retrospectively analyzed cases of active TB diagnosed between January 1995 and December 2010 in our cohort of HIV-infected patients. This open cohort was made up of HIV-1-infected subjects who had been followed for up to 16 years. We classified individuals as having active TB if they had at least one positive culture for M. tuberculosis, a positive smear for alcohol-acid resistant bacilli, or if they started a TB treatment regimen. We defined the date of onset of TB as the date of the first positive smear or culture. If neither a smear nor culture result were available before a TB treatment regimen was initiated, the starting date of the treatment was considered to be the date of onset. All physicians providing care to patients were infectious disease specialists, and patients were seen at 4-6 month intervals. TB was treated in accordance with Brazilian guidelines for TB control $^{2,7}$. We defined patients as 'lost to follow up' if they did not visit the clinic within a 6-month period and did not respond to three attempts of us contacting them by telephone and/or telegrams. PPD was performed as a routine screening at the beginning of the follow up; however, prophylaxis was not reported for most patients from this cohort. The study was approved by the Ethical Board (Cappesq number 0211/2010).

Statistical analysis: We analyzed data using Epidata software (Centers for Disease Control and Prevention, Atlanta, GA) and compared predictor variables among TB/HIV patients and those HIV patients without TB. For continuous variables, we used nonparametric KruskalWallis tests, and for discrete variables we used the Fisher exact test. We calculated survival estimates by the Kaplan-Meier method and compared survival curves by the log-rank test using Stata 11.0 software (Stata Corporation, College Station, TX). A pH value lower than 0.05 was considered significant.

(1) Secondary Immunodeficiencies outpatient clinic, Dermatology Department, São Paulo University Medical School. São Paulo, SP, Brazil.

(2) Preventive Medicine Department, São Paulo University Medical School. São Paulo, SP, Brazil.

(3) Institute of Tropical Medicine of São Paulo, Laboratory of Dermatology and Immunodeficiencies/LIM56, University of São Paulo. São Paulo, SP, Brazil.

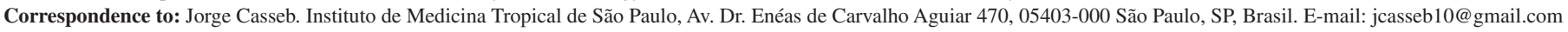




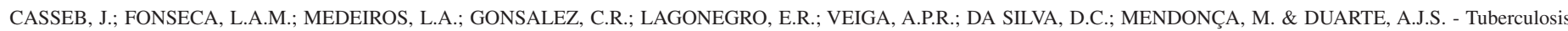
among HIV-1-infected subjects in a tertiary out-patient service in São Paulo city, Brazil. Rev. Inst. Med. Trop. Sao Paulo, 54(5): 257-9, 2012.

\section{RESULTS}

Five hundred and ninety-nine patients were enrolled in the open cohort, and $41(6.8 \%)$ met our case definition for TB. Twenty-nine (71\%) were newly diagnosed with TB, twelve (29\%) had known TB at the time of cohort entry, and most were on HAART. Thirty patients had pulmonary tuberculosis and eleven had extra-pulmonary disease (three patients had lymph node tuberculosis, two had intra-abdominal disease, two had disseminated tuberculosis, two neuro-tuberculosis, one had pericardial and another one had pleural disease). In general, patients with TB were younger, more likely to be male, and had higher viral loads $\left(5.76 \log _{10}\right.$ copies $/ \mathrm{mL}$ vs. $4.65 \log _{10}$ copies $/ \mathrm{mL}$ ) at the time of TB diagnosis than those without TB, although none of those characteristics has reached statistical significance (Table 1). Twenty-one TB patients were on HAART, but only three had undetectable viral loads. The remaining 20 patients were not on antiretrovirals. Among patients with other, non-TB opportunistic infections 59 had detectable viral loads, while 19 had undetectable levels.

Tuberculosis incidence was 1.47 cases per 100 person-years over a total cohort follow-up time of 2775 person-years. Comparing patients diagnosed with TB to those diagnosed with other AIDS-defining opportunistic infections, eight (19.5\%) of 41 patients with TB were lost to follow up and six (14.6\%) died, in comparison with eight deaths (4.8\%) among 168 non-TB AIDS patients. All TB patients who died were on HAART, five of them with rescue regimens. Death rates were 2.17 per 100 person-year among TB patients and 0.9 per 100 person-years among non-TB AIDS patients. The probability of surviving up to 10 years after diagnosis was $75 \%$ for TB patients as opposed to $96 \%$ for patients with other, non-TB opportunistic infections ( $p=0.03$ ) (Fig. 1).

\section{DISCUSSION}

We found that $6.8 \%$ of HIV-infected patients in our cohort had TB on cohort entry or developed it during follow up, corresponding to an incidence of 1.47 cases per 100 person-year. TB is endemic in Brazil, especially in metropolitan areas where the living conditions and poverty of parts of the population facilitate the spread of airborne diseases. The relatively high incidence of TB in our study population of HIV-infected patients is similar to that found by other investigators studying poor, urban populations in Latin America ${ }^{2,6}$.

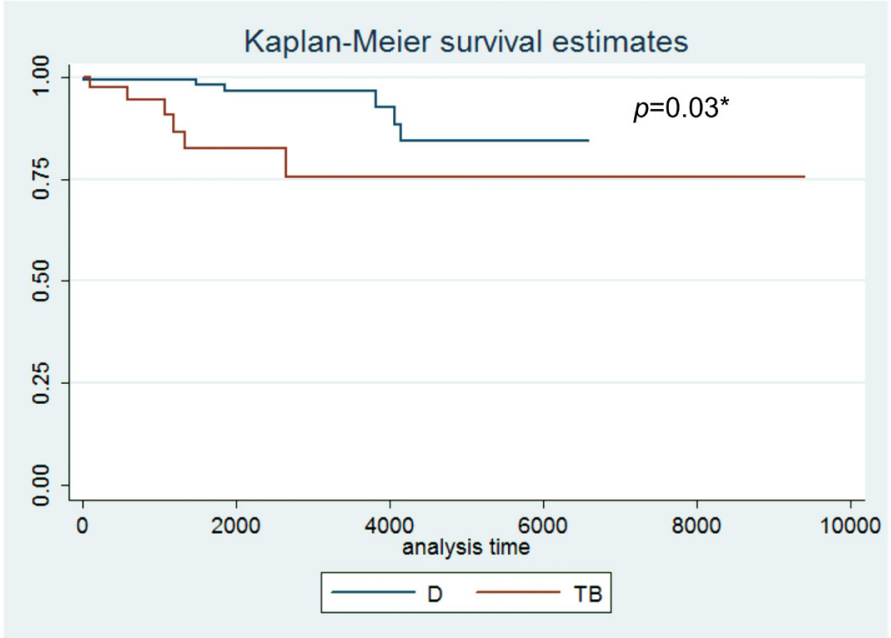

Fig. 1 - Survival estimates of AIDS patients with tuberculosis and of AIDS patients with other opportunistic diseases. São Paulo, Brazil, 1995-2010. Notes: Analysis time in days; $\mathrm{D}=$ Patients with other opportunistic non-TB diseases; TB = Patients with tuberculosis; * Log-rank test.

We also found that TB was an important cause of mortality in our study, with six confirmed deaths and eight lost to follow up, some or all of whom may have died from TB, although we were unable to ascertain this fact. This number, although substantially lower than the numbers found in several African countries where TB reaches up to $90 \%$ of prevalence among AIDS patients ${ }^{8}$, is nonetheless a cause for concern since the risk of dying from TB is more than twice that of dying from any other opportunistic disease ${ }^{9}$. Even so, confirmed mortality from TB was not as high in this cohort (1\%) as it is in Africa and Asia, possibly due to the more widespread use of $\mathrm{ART}^{10}$, as well as to an earlier diagnosis of HIV infection ${ }^{11,12}$. In this respect, we found that only slightly more than half of our TB/HIV patients were on HAART, and just three of them had undetectable viral loads, suggesting an unsatisfactory adherence to treatment.

Our findings provide evidence in support of the current Brazilian national tuberculosis treatment guidelines, which recommend an

Table 1

Demographic, clinical and laboratory characteristics of TB patients compared to non-TB patients*. São Paulo, Brazil, 1995-2010

\begin{tabular}{|c|c|c|c|}
\hline Variable & $\begin{array}{c}\text { TB/HIV cases } \\
(n=41)\end{array}$ & $\begin{array}{l}\text { Non-TB AIDS cases } \\
(\mathrm{n}=168)\end{array}$ & $p$ value \\
\hline Age (mean \pm sd) years & $41.2(9.4)$ & $43.4(10.4)$ & 0.5 \\
\hline Gender ( $\%$ male $)$ & 78.0 & 72.6 & 0.6 \\
\hline Mean time of HIV infection to disease diagnosis (years) & 5.96 & 2.44 & 0.01 \\
\hline Nadir of T CD4 cells/mm³ (Median, 25\%-75\%) & $173(73-249)$ & $150(58-239)$ & 0.7 \\
\hline $\mathrm{T}$ CD4 cells $/ \mathrm{mm}^{3}$ at disease diagnosis (Median, $25 \%-75 \%$ ) & $193(66-404)$ & $167(178-344)$ & 0.6 \\
\hline Proportion on HAART(\%) & 59 & 48 & 0.8 \\
\hline RNA HIV viral load $\log _{10} / \mathrm{mL}$ & $5.19(4.03-5.7)$ & $4.65(4.1-5.3)$ & 0.7 \\
\hline Deaths, n $(\%)$ & $6(15)$ & $8(5)$ & 0.03 \\
\hline
\end{tabular}

ns: Not statistically significant; * All comparisons between TB/HIV cases vs Non-TB AIDS cases. 
CASSEB, J.; FONSECA, L.A.M.; MEDEIROS, L.A.; GONSALEZ, C.R.; LAGONEGRO, E.R.; VEIGA, A.P.R.; DA SILVA, D.C.; MENDONÇA, M. \& DUARTE, A.J.S. - Tuberculosis among HIV-1-infected subjects in a tertiary out-patient service in São Paulo city, Brazil. Rev. Inst. Med. Trop. Sao Paulo, 54(5): 257-9, 2012.

evaluation of HIV-infected patients for TB on entry into care and to treat those found to be infected regardless of clinical stage. In our cohort, all patients with clinical TB received a TB treatment regimen based on the then-current guidelines, which consisted of triple anti-TB therapy for six months (rifampin, isoniazid and pyrazinamide). More recently, the national treatment guidelines have been reviewed to include ethambutol in the treatment regimen and to provide drugs in a fixed-dose combination once daily for six months, free of charge ${ }^{2}$.

There are several limitations for this study. Firstly, this study was conducted in a tertiary care hospital, and patient care provided in our institution may not be representative of care in other types of clinical facilities in Brazil. Secondly, as this was an observational study, we were unable to control adherence, which could have led to an underestimation of the effectiveness of TB treatment in this population. Finally, much of the data regarding isoniazid prophylaxis was not systematically recorded, and so we were unable to determine the impact of this important intervention on TB incidence.

However, despite these limitations, we believe that our finding that $\mathrm{TB}$ is a major cause of morbidity and mortality is valid, despite the widespread use of ART in Brazil. This in turn suggests the need for additional interventions, such as the use of new diagnostic tools, INH prophylaxis and directly observed therapy to minimize the burden of HIV-related TB in Brazil. Thus the early diagnosis and treatment, either of TB and HIV infection, the identification of risk factors and the use of INH, should be improved in this population.

\section{RESUMO}

\section{Tuberculose entre pacientes infectados pelo HIV-1 em ambulatório terciário de São Paulo, Brasil}

Atualmente, a tuberculose (TB) é considerada a doença infecciosa mais importante entre os pacientes infectados pelo HIV-1 nos países em desenvolvimento, como o Brasil. Análise retrospectiva dos casos de tuberculose ocorridos a partir de janeiro 1995 até dezembro de 2010 foi realizada em nossa coorte de 599 pacientes HIV positivos. O desfecho primário foi a ocorrência de TB ativa, e 41 casos da doença foram diagnosticados durante este período de 16 anos. As contagens médias do nadir de células T CD4 e ao momento do diagnóstico de TB foram de 146 e 217 células $/ \mathrm{mm}^{3}$, respectivamente. A carga viral média de HIV foi de $5,19 \log _{10}$ cópias $/ \mathrm{mL}$, e $59 \%$ dos pacientes estavam em tratamento com ART. A incidência de TB foi de 1,47 casos por 100 pessoas-ano, para um tempo total de seguimento da coorte de 2775 pessoas-ano. A probabilidade de sobreviver até 10 anos após o diagnóstico foi de $75 \%$ para pacientes com TB, em oposição a $96 \%$ para pacientes com outras doenças oportunistas não-TB $(p=0,03)$. A tuberculose pode ser considerada problema de saúde pública entre as pessoas que vivem com HIV no Brasil, apesar da ampla utilização de anti-retrovirais para o tratamento da infecção pelo HIV / AIDS

\section{REFERENCES}

1. Brasil. Ministério da Saúde. Secretaria de Vigilância em Saúde. Tuberculose no Brasil: realidade e perspectivas. Boletim 1/2012 Tuberculose no Brasil. Available from: http://portalsaude.saude.gov.br/portalsaude/index.cfm?portal=pagina.visuali zarTexto\&codConteudo $=6406 \&$ codModuloArea $=783 \&$ chamada=boletim- $1 / 2012$ -tuberculose-no-brasil

2. Brasil. Ministério da Saúde. Secretaria de Vigilância em Saúde. Programa Nacional de Controle da Tuberculose. Manual de recomendações para o controle da tuberculose no Brasil. 2010. Available from: http://portal.saude.gov.br/portal/arquivos/pdf/ manual_de_recomendacoes_controle_tb_novo.pdf

3. Casseb J, Fonseca LA, Veiga AP, de Almeida A, Bueno A, Ferez AC, et al. AIDS incidence and mortality in a hospital-based cohort of HIV-1-seropositive patients receiving highly active antiretroviral therapy in São Paulo, Brazil. AIDS Patient Care STDS. 2003;17:447-52.

4. Corbett EL, Marston B, Churchyard GJ, De Cock KM. Tuberculosis in sub-Saharan Africa: opportunities, challenges, and change in the era of antiretroviral treatment. Lancet. 2006;367:926-37.

5. Golub JE, Saraceni V, Cavalcante SC, Pacheco AG, Moulton LH, King BS, et al. The impact of antiretroviral therapy and isoniazid preventive therapy on tuberculosis incidence in HIV-infected patients in Rio de Janeiro, Brazil. AIDS. 2007;21:1441-8.

6. Granich R, Akolo C, Gunneberg C, Getahun H, Williams P, Williams B. Prevention of tuberculosis in people living with HIV. Clin Infect Dis. 2010;50(Suppl 3):S215-22.

7. Gutierrez EB, Gomes V, Picone CM, Suga H, Atomiya AN. Active tuberculosis and Mycobacterium tuberculosis latent infection in patients with HIV/AIDS. HIV Med. 2009;10:564-72.

8. Pacheco AG, Saraceni V, Tuboi SH, Lauria LM, Moulton LH, Faulhaber JC, et al. Estimating the extent of underreporting of mortality among HIV-infected individuals in Rio de Janeiro, Brazil. AIDS Res Hum Retroviruses. 2011;27:25-8.

9. Pettit AC, Barkanic G, Stinnette S, Rebeiro P, Blackwell R, Raffanti SP, et al. Potentially preventable tuberculosis among HIV-infected persons in the era of highly active antiretroviral treatment. Int J Tuberc Lung Dis. 2009;13:355-9.

10. Santoro-Lopes G, de Pinho AM, Harrison LH, Schechter M. Reduced risk of tuberculosis among Brazilian patients with advanced human immunodeficiency virus infection treated with highly active antiretroviral therapy. Clin Infect Dis. 2002;34:543-6

11. Saraceni V, King BS, Cavalcante SC, Golub JE, Lauria LM, Moulton LH, et al. Tuberculosis as primary cause of death among AIDS cases in Rio de Janeiro, Brazil. Int J Tuberc Lung Dis. 2008;12:769-72.

12. Whalen C, Horsburgh CR Jr, Hom D, Lahart C, Simberkoff M, Ellner J. Site of disease and opportunistic infection predict survival in HIV-associated tuberculosis. AIDS 1997;11:455-60.

13. World Health Organization. Global tuberculosis control: a short update to the 2009 report. [Cited: 2010 Nov 3]. Available from: http://www.who.int/tb/publications/ global_report/2009/update/en/index.html

Received: 7 November 2011

Accepted: 3 July 2012 


\section{LIBRARY OF THE \\ SÃO PAULO INSTITUTE OF TROPICAL MEDICINE}

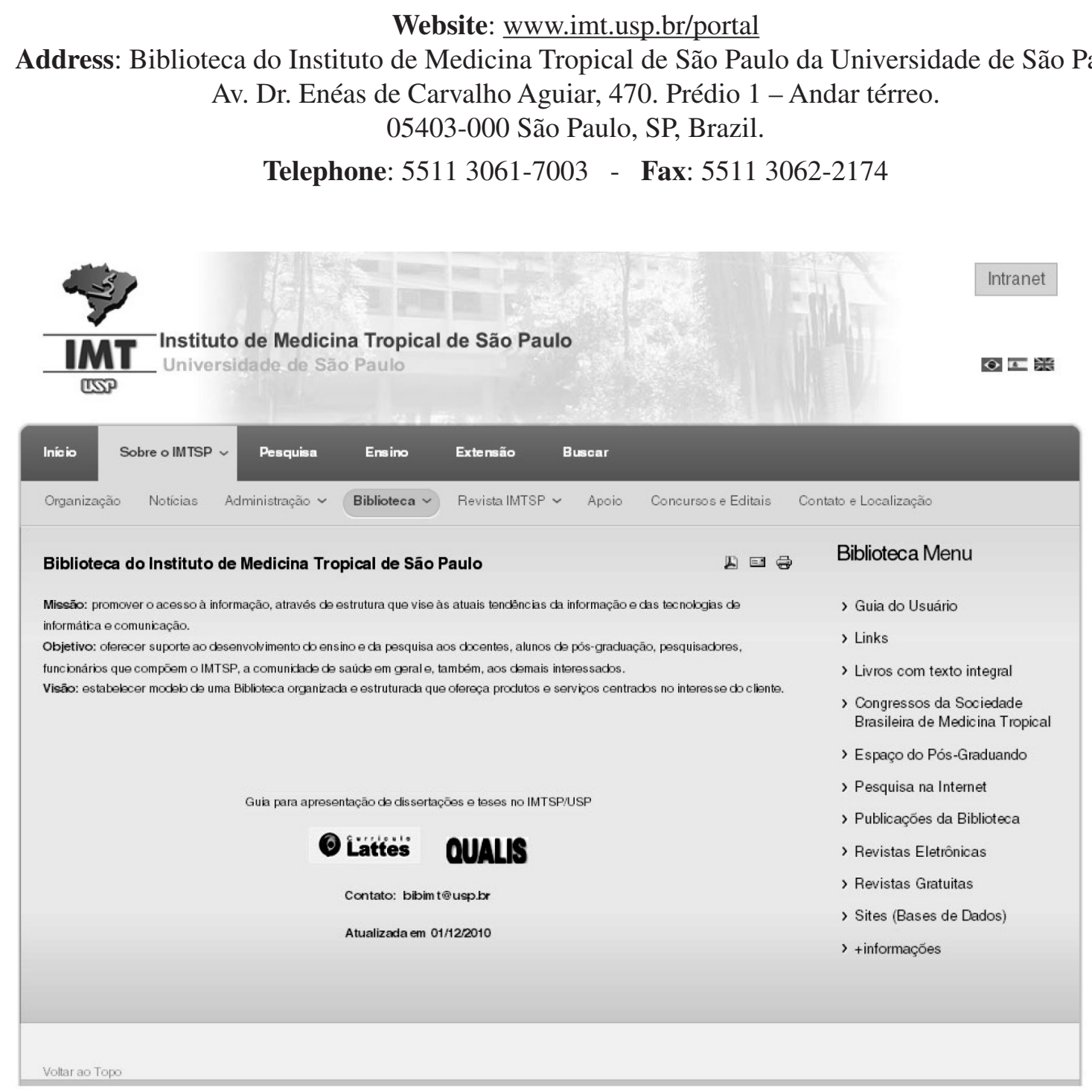

The Library of the São Paulo Institute of Tropical Medicine (IMTSP Library) was created on January 15, 1959 in order to serve all those who are interested in tropical diseases. To reach this objective, we select and acquire by donation and / or exchange appropriate material to be used by researchers and we maintain interchange between Institutions thorough the Journal of the São Paulo Institute of Tropical Medicine, since the Library has no funds to build its own patrimony.

The IMTSP Library has a patrimony consisting of books, theses, annals of congresses, journals, and reference works.

The collection fo journals existing in the Library can be verified through the USP - Bibliographic Database - OPAC - DEDALUS http://dedalus.usp.br:4500/ALEPH/eng/USP/USP/DEDALUS/start of the USP network. 